Power". This was followed by lectures on the physics of advanced reactors, the zero-energy fast breeder reactor, effects of irradiation on the physical properties of solids, shielding, control, instrumentation, chemistry and metuallurgy in a nuclear energy project, and the uses of reactors; Prof. R. E. Peierls gave an evening discourse on "Recent Developments in Nuclear Theory". Speakers came from Britain, the United States and Canada. An informal dinner was arranged for overseas visitors, who were also entertained at a Government reception. During the meeting there was an exhibition of books and of apparatus. The lectures, with the exception of that by Prof. Peierls, will be published as a supplement to the British Journal of Applied Physics ; the programme of the conference includes full abstracts of the lectures.

\section{Commonwealth-American Universities Conference}

The Commonwealth-American Universities Conference, at which university presidents from the United States representing the Association of American Universities will participate with vicechancellors of United Kingdom and Commonwealth Universities, will be held this year in London and Birmingham during July 10-17 under the auspices of the Association of Universities of the British Commonwealth. The sessions in London will be opened by a reception on the evening of July 10 in the Senate House of the University of London at which H.M. the Queen Mother will be present as Chancellor of the University. Discussions will be held in London on the general question of "University Expansion in relation to Population Trends", with particular emphasis on the effect of the approaching 'bulge' in the university age-group in the United States and in various countries of the Commonwealth. The members of the Conference will visit Exeter on July 13 for the ceremony of installation of Mary, Duchess of Devonshire, as first chancellor of the new University. On the following day members will meet in Birmingham, where discussions will be held on a series of problems common to universities in Britain and the United States, such as the adequacy of school preparation for college and university students, the need for an expanding curriculum to meet new world needs, and the relationships of university administration to students, faculties and governing boards.

\section{Royal Meteorological Society : Officers for 1956-7}

THE following have been elected officers of the Royal Meteorological Society for the year 1956-57: President, Dr. R. C. Sutcliffe ; Vice-Presidents, Prof. G. Manley, Sir Graham Sutton, R. G. Veryard and Dr. T. W. Wormell ; Vice-President for Canada, Dr. D. P. MeIntyre; Vice-President for Scotland, J. R. Atkinson; Treasurer, Dr. J. S. Farquharson; Secretaries, P. J. Meade, Dr. H. L. Penman, Dr. A. G. Forsdyke (Librarian) and Dr. G. D. Robinson (Editor).

\section{Announcements}

Tre gold Albert Medal of the Royal Society of Arts has been awarded for 1956 to Sir Henry Dale, "for eminent service to science, particularly physiology".

Ar the annual general meeting of the Marine Biological Association of the United Kingdom, held on June 27, Mr. E. H. E. Havelock, Dr. A. G. Huntsman and Dr. A. C. Redfield were elected honorary members of the Association.

The Council of the Royal Society has awarded the Tropical Research Fellowship (Medical Sciences) to Dr. D. G. Jamison, of Corpus Christi College, Oxford, for his work on the histopathology of leprosy with particular reference to the relationship of the mycobacteria to cutaneous nerve fibres.

Dame Caroline HasletT is resigning from the post of director of the Electrical Association for Women, which she has held since its inception thirty-two years ago.

Dr. Gerard KIeIn, lecturer in theoretical physics in the Royal Holloway College, London, has been appointed senior lecturer in mathematics in the Royal Technical College, Glasgow.

Tre following have been appointed to lectureships in The Queen's University of Belfast : L. J. Symons (geography), Dr. F. A. Lewis (inorganic chemistry) and R. Taggart (mechanical engineering).

THE following have been appointed to lectureships in the University of Birmingham: Dr. J. G. Valatin (mathematical physics), Dr. C. A. Doran and Dr. P. M. Rolph (physics), Dr. L. W. Poel (botany), Dr. G. T. Wright (electrical engineering) and Dr. J. J. Pick (industrial metallurgy).

ThE British Iron and Steel Research Association will hold two 'open days' at its Sheffield Laboratories on September 6 and 7, for representatives of member firms.

The United Nations Food and Agriculture Organization is holding an international meeting of inland fisheries workers in Helsinki during July 24-26, at which inland fisheries in relation to world food economy will be reviewed. The European member nations of the Organization will be sending represent. atives and, at the same time, biologists at the Thir. teenth International Limnological Congress, which is being held in Helsinki during July 27-August 7, have also been invited to attend as observers.

A RESIDENTIAL course on rural studies, organized by the Institute of Rural Life at Home and Overseas, will be held at the Essex Institute of Agriculture, Writtle, near Chelmsford, Essex, during September 2-15. The course will be of a general nature, but tropical conditions will be included and the course should appeal to workers and students from overseas. The fee is £14. Application should be made not later than July 27 to the Secretary of the Institute, 59 Bryanston Street, Marble Arch, London, W.1, from whom further information can be obtained.

A symposrum on "Recent Studies in Yeast and their Significance for Industry", arranged jointly by the Dublin Section and the Food and Microbiology Groups of the Society of Chemical Industry, will be held in Dublin at the Rupert Guinness Hall during September 17-18 (and possibly 19). The Biochemical Society, which is meeting in Dublin during September 14-16, is arranging sightseeing tours for the afternoon of September 15 and for the whole of the succeeding day; members attending the symposium can join these tours. Further information can be obtained from the honorary secretary of the Dublin Section of the Society of Chemical Industry, Dr. A. K. Mills, Arthur Guinness Son and Co. (Dublin), Ltd., Chemists' Laboratories, St. James's Gate, Dublin. 